\title{
TRIALS FOR PREPARATION OF COMBINED INACTIVATED VACCINE AGAINST RESPIRATORY VIRAL DISEASES OF POULTRY (ND-IB-ILT)
}

\section{ABD EL-KHALECK, M.A.}

Veterinary Serum and Vaccine Research Institute, ARC, Ministry of Agriculture, Dokki Giza - Egypt

(Manuscript received 14 May 2006)

\section{Abstract}

One hundred and seventy susceptible chicks, 21 days old, were divided into four main groups. The $1^{\text {st }}, 2^{\text {nd }}$ and $3^{\text {rd }}$ groups were vaccinated by three different designed combined oil inactivated vaccines against Newcastle (ND), Infectious Bronchitis (IB) and Infectious Laryngo-tracheitis (ILT) diseases viruses while the $4^{\text {th }}$ group was kept as control. Half of each vaccinated group was boostered three weeks later by the corresponding prepared vaccine. Blood and serum samples were collected for evaluation of cellular and humoral immune responses. Estimation of cell mediated immunity was carried out using lymphocyte blastogenesis and phagocytic activity. Better response was obtained in the $1^{\text {st }}$ group at 2 weeks post initial vaccination and 1 week after boostering. There is a decrease in the heterophil/lymphocyte ratio in group 1 in comparison with the highest ratio in control group. The humoral immune response was detected by haemagglutination inhibition test for NDV, serum neutralization test (SNT) and ELISA test for IBV and SNT for ILT virus. The highest value of the antibody titre was recorded for the $1^{\text {st }}$ designed vaccine followed by the $2^{\text {nd }}$ designed vaccine and finally the $3^{\text {rd }}$ designed vaccine.

\section{INTRODUCTION}

Newcastle disease (ND), Infectious Bronchitis (IB) and Infectious Laryngotracheitis (ILT) are the major viral respiratory diseases causing serious problems facing the rapidly expanding poultry industry in Egypt which lead to considerable economic losses due to high morbidity, mortality rates and drop in meat and egg production.

Newcastle disease is well established and widespread throughout the whole country commonly assuring an acute and subacute form (Daubeny and Mansy, 1947). Infectious bronchitis is primarily respiratory disease, together with egg production problems that may occur when infection of oviduct are of early ages. Significant mortality may occur in young ages particularly if the disease exacerbated by secondary pathogens (Hofstad, 1984). Similarly, infectious laryngotracheitis is an upper respiratory disease of chickens that appears periodically in areas of concentrated poultry production and causes tremendous economic losses (Hanson and Bagust, 1991). 
The main advantage of combined vaccines is providing protection against more than one disease at the same time. Besides, the combined vaccines reduce time, labour, stress reactions and costs of vaccination. So, the aim of this study is the preparation of combined oil emulsion inactivated viral respiratory vaccine to protect chickens against ND, IB and ILT diseases at one shot.

\section{MATERIALS AND METHODS}

\section{Viral strains}

All vaccinal and virulent strains were kindly obtained from Newcastle Disease Department, Veterinary Serum and Vaccine Research Institute (VSVRI), Abbasia, Cairo, Egypt.

1. Newcastle Disease vaccinal strain "LaSota strain"

Its original titre was $10^{10.6} \mathrm{EID}_{50} / \mathrm{ml}$.

\section{Infectious bronchitis vaccinal strain}

a. IBV M41 classical strain: Its titre was $10^{6.9} \mathrm{EID}_{50} / \mathrm{ml}$.

b. IBV D274 variant strain: Its titre was $10^{7} \mathrm{EID}_{50} / \mathrm{ml}$.

\section{Infectious laryngotracheitis vaccinal strain}

Its titre was $10^{6} \mathrm{EID}_{50} / \mathrm{ml}$.

\section{Laboratory host system}

\section{Embryonated chicken eggs}

Specific pathogen free (SPF) embryonated chicken eggs, 10 days old, were obtained from Nile SPF eggs, Koom Oshiem, Fayoum, Egypt and used for propagation, titration, assurance of complete virus inactivation and preparation of chicken embryo fibroblast (CEF) primary cell culture.

\section{Chickens}

One hundred and seventy of one day old chicks were obtained from private farm and kept under strict hygienic measures in isolated and disinfected cages till 21 days old. The chicks were proved to be seronegative for ND, IB and ILT viruses.

\section{Chicken embryo fibroblast (CEF)}

CEF cell cultures were used for propagation and titration of ILT batch to be used in serum neutralization test.

\section{Enzyme linked immunosorbent assay (ELISA) kit}

The pro Flok ELISA kit was used and the plate was read using EUSA reader at 650.

\section{Viruses propagation and titration}

NDV "LaSota strain", IBV "M41 strain), IBV D274 strain and ILT viruses were propagated and titrated in SPF embryonated chicken eggs. The titres were $10^{11.3}$, $10^{7.24}, 10^{7.37}$ and $10^{7} \mathrm{EID}_{50} / \mathrm{ml}$, respectively. 


\section{Inactivation of vaccinal batches}

Inactivation of each virus suspension of NDV and two IB virus batches (M41 and D274) were carried out using formalin in a final concentration of $0.1 \%$ while ILT was inactivated using binary ethyleneimine (BEI) in a concentration of $1200 \mu \mathrm{g} / \mathrm{ml}$ according to Barhoom et al. (1986). All the viral fluids were blended using magnetic stirrer for 24 hours at room temperature. Samples from the inactivated viruses were tested in 10 days old SPF embryonated chicken eggs $(0.2 \mathrm{ml} / \mathrm{egg})$, three successive blind passages were carried out for assurance of complete inactivation.

\section{Vaccinal Design}

Three combined oil emulsion inactivated vaccines were designed using three different titres per dose for each vaccinal virus and these vaccines were corresponded to the chicken groups as follow:

a. First vaccine was prepared using ND, IB M41, IB D274 and ILT vaccinal viruses by titres $10^{11}, 10^{6.94}, 10^{7.07}$ and $10^{6.7}$ respectively per dose and corresponded to group1.

b. Second vaccine was prepared using ND, IB M41, IB D274 and ILT vaccinal viruses by titres $10^{10}, 10^{5.94}, 10^{6.07}$ and $10^{5.7}$ respectively per dose and corresponded to group 2.

c. Third vaccine was prepared using ND, IB M41, IB D274 and ILT vaccinal viruses by titres $10^{9}, 10^{4.94}, 10^{5.07}$ and $10^{4.7}$ respectively per dose and corresponded to group3.

All these oil vaccines were prepared according to Stone et al. (1978) and injected $0.5 \mathrm{ml} /$ bird $\mathrm{I} / \mathrm{M}$.

\section{Quality control of the prepared vaccines}

\section{Purity and sterility test}

The prepared vaccines were tested to be free from any contamination according to Code of American Federal Regulations (1985).

\section{Safety test}

Ten chicks of 21 days old were injected intramuscularly (I/M) with double field dose/bird for each prepared vaccine and observed for 15 days for any abnormalities or deaths.

\section{Efficacy of the prepared vaccines}

For the efficacy of the prepared vaccines, the following parameters were carried out. 


\title{
1. Evaluation of cell mediated immune response
}

\section{a. Lymphocyte blastogenesis assay}

It was carried out by tetrazolium calorimetric assay according to Mosmann (1983) and the results were expressed as delta optical density ( $\Delta O D)$.

\section{b. Macrophage activity test}

It was done by the modified method according to El-Enbawy (1990). The percentage of phagocytosis and phagocytic index were calculated as follow:

No. of phagocytes which ingest candida

\author{
Phagocytic \% $=$----- X 100 \\ Total No. of phagocytes \\ Total No. of phagocytes which ingest more than two candida
}

Phagocytic index $=$

Total No. of phagocytes which ingest candida

\section{c. Heterophil/lymphocyte ratio}

It was carried out according to Gross and Siegel (1983).

\section{Evaluation of humoral immune response}

\section{a. Haemagglutination inhibition test}

It was performed to determine the haemagglutinating antibodies against ND according to Majujabe and Hitchner (1977).

\section{b. Enzyme linked immunosorbent assay}

The antibody titres against IBV were estimated using ELISA kits (KPL Laboratories, Maryland, USA) according to the manufacturer's instructions.

\section{c. Serum neutralization test}

It was used for estimation of neutralizing antibodies titres against ILT virus by the method of Cunningham (1973). The antibody titres were calculated as the reciprocal of serum dilution which neutralize $100-200$ TCID $_{50}$ of ILT virus.

\section{Experimental Design}

One hundred and seventy susceptible chicks, 21 days old were divided into four main groups. The $1^{\text {st }}, 2^{\text {nd }}$ and $3^{\text {rd }}$ groups were equal (50 chicks for each) and vaccinated by three different designed combined oil inactivated vaccines against ND, IB and ILT diseases while $4^{\text {th }}$ group (20 chicks) was kept as negative control. Half of each vaccinated group ( 25 chicks was boostered three weeks later by the same corresponding prepared vaccine. Blood and serum samples were collected for evaluation of cellular and humoral immune response respectively. 


\section{RESULTS AND DISCUSSION}

Respiratory diseases of poultry play a major economic importance. Many of these diseases or infections introduced into geographic area can explode into an epidemic and may have a significant negative effect on international trade. Respiratory diseases are continuing to cause high economic losses in many areas world-wide due to increased mortality rates, decreased weight gain and egg production, increased medication costs and increased feed conversion rates (Hafez, 2006).

Estimation of cell mediated immune response was carried out using lymphocyte blastogenesis (Table 1 ), it was shown that its maximum value $(0.046)$ was obtained in group (1) at the $2^{\text {nd }}$ WPV and one week after boostering $(0.024)$ then declined till reach its minimum value at five WPV $(0.015)$ and two WPV after boostering (0.017) in comparison with other groups.

The results of phagocytic activity (Table 2) were parallel to the results of lymphocyte blastogenesis. The heterophil/lymphocyte ratio was illustrated in table (3), the lowest ratio was obtained in group (1) which reached $(0.117)$ on the $2^{\text {nd }}$ WPV while in groups (2) and (3) reached (0.182) three WPV and (0.187) two WPV, respectively.

These results are in agreement with Timms and Bracewell (1983) who stated that once the humoral immune response become established there is a corresponding decrease in the phagocytic activity.

Regarding the mean value of ND HI titre, Table (4) showed that the highest titre was noticed in group (1) ( 9.3 single dose) and ( 10.6 boostered dose) at $8^{\text {th }}$ WPV, while group (3) recorded the lowest HI antibody titres.

Table (5) showed that the ELISA antibody titre for IB reached its maximum value in group (1) (3622 single dose) and (3945 boostered dose) at $8^{\text {th }}$ and $6^{\text {th }}$ WPV respectively and still high till the $12^{\text {th }}$ WPV, while group (3) recorded the lowest titre.

Results in table (6) recorded that the neutralizing antibody titre for IB in group (1) showed significant rise from the $4^{\text {th }}$ WPV till the $10^{\text {th }}$ WPV $(512-2048)$ then declined to 1024 on the $12^{\text {th }}$ WPV while group (3) recorded the lowest titres which ranged from (16-128).

The results agreed with Gelb et al. (1989) who found that the combination between the variant and classical strains of vaccines gave higher levels of serological response than the homologous type of the viral vaccine.

Humoral immune response of ILT vaccine was estimated using SNT as shown in table (7) which revealed that serum neutralizing antibody titre of group (1) recorded the highest titre in both single and booster doses (128) and (256) respectively at $6^{\text {th }}$ WPV when compared with other corresponding single and booster vaccinated groups. 
In conclusion, the $1^{\text {st }}$ designed vaccine which prepared using ND, IB (M41 and D274) and ILT by titres $10^{11}, 10^{6.94}, 10^{7.07}$ and $10^{6.7} /$ dose respectively offered the best cellular and humoral immune responses either in single or boostered experimental vaccinated groups.

Table 1. Lymphocyte transformation test expressed as Delta optical density.

\begin{tabular}{|c|c|c|c|c|c|c|c|}
\hline \multirow{2}{*}{$\begin{array}{l}\text { Weeks post } \\
\text { vaccination }\end{array}$} & \multicolumn{7}{|c|}{ Groups } \\
\hline & \multicolumn{2}{|c|}{1} & \multicolumn{2}{|c|}{2} & \multicolumn{2}{|c|}{3} & 4 \\
\hline 1 & \multicolumn{2}{|c|}{0.036} & \multicolumn{2}{|c|}{0.022} & \multicolumn{2}{|c|}{0.021} & 0.005 \\
\hline 2 & \multicolumn{2}{|c|}{0.046} & \multicolumn{2}{|c|}{0.031} & \multicolumn{2}{|c|}{0.033} & 0.008 \\
\hline 3 & \multicolumn{2}{|c|}{0.032} & \multicolumn{2}{|c|}{0.022} & \multicolumn{2}{|c|}{0.018} & 0.005 \\
\hline 4 & 0.019 & $0.024 *$ & 0.014 & $0.016^{*}$ & 0.011 & $0.017^{*}$ & 0.004 \\
\hline 5 & 0.015 & 0.017 & 0.011 & 0.012 & 0.010 & 0.012 & 0.003 \\
\hline
\end{tabular}

* Chickens received booster dose from each group.

Group (1): Chickens vaccinated by ND, IB, M41, IB D274 and ILT by titres $10^{11}, 10^{6.94}$, $10^{7.07}$ and $10^{6.7}$ respectively/dose.

Group (2): Chickens vaccinated by ND, IB, M41, IB D274 and ILT by titres $10^{10}, 10^{5.94}$, $10^{6.07}$ and $10^{5.7}$ respectively/dose.

Group (3): Chickens vaccinated by ND, IB, M41, IB D274 and ILT by titres $10^{9.0}, 10^{4.94}$, $10^{5.07}$ and $10^{4.7}$ respectively/dose.

Group (4): Chickens non-vaccinated control group.

Table 2. Phagocytic activity of different groups expressed by phagocytic percentage

\begin{tabular}{|c|c|c|c|c|c|c|}
\hline \multirow{2}{*}{} & \multicolumn{7}{|c|}{ Weeks Post Vaccination } \\
\cline { 2 - 7 } Groups & \multicolumn{2}{|c|}{$1^{\text {st }}$ week } & \multicolumn{2}{c|}{$2^{\text {nd }}$ week } & \multicolumn{2}{c|}{$3^{\text {rd }}$ week } \\
\cline { 2 - 7 } & $\%$ & Index & $\%$ & Index & $\%$ & Index \\
\cline { 2 - 7 } & 64.7 & 0.909 & 75 & 0.916 & 70.4 & 0.69 \\
\hline 2 & 56 & 0.753 & 60 & 0.833 & 53.6 & 0.51 \\
\hline 3 & 52 & 0.692 & 60 & 0.75 & 50.5 & 0.40 \\
\hline 4 & 11.11 & 0.100 & 10.5 & 0.09 & 10 & 0.08 \\
\hline
\end{tabular}


Table 3. Heterophil lymphocyte ratio of chickens vaccinated with different doses of combined oil inactivated vaccine.

\begin{tabular}{|c|c|c|c|c|c|c|c|}
\hline \multirow{2}{*}{$\begin{array}{l}\text { Weeks post } \\
\text { vaccination }\end{array}$} & \multicolumn{7}{|c|}{ Groups } \\
\hline & \multicolumn{2}{|c|}{1} & \multicolumn{2}{|c|}{2} & \multicolumn{2}{|c|}{3} & 4 \\
\hline 1 & \multicolumn{2}{|c|}{0.367} & \multicolumn{2}{|c|}{0.371} & \multicolumn{2}{|c|}{0.420} & 1.38 \\
\hline 2 & \multicolumn{2}{|c|}{0.117} & \multicolumn{2}{|c|}{0.189} & \multicolumn{2}{|c|}{0.187} & 1.20 \\
\hline 3 & \multicolumn{2}{|c|}{0.117} & \multicolumn{2}{|c|}{0.182} & \multicolumn{2}{|c|}{0.200} & 1.77 \\
\hline 4 & 0.122 & $0.111 *$ & 0.232 & $0.177 *$ & 0.283 & $0.192^{*}$ & 1.80 \\
\hline 5 & 0.124 & 0.112 & 0.297 & 0.280 & 0.306 & 0.200 & 1.13 \\
\hline
\end{tabular}

* Chickens received booster dose from each group.

Table 4. NDV haemagglutinating antibody titres in groups of vaccinated and nonvaccinated chickens.

\begin{tabular}{|c|c|c|c|c|c|c|c|}
\hline \multirow{2}{*}{$\begin{array}{l}\text { Weeks post } \\
\text { vaccination }\end{array}$} & \multicolumn{7}{|c|}{ Groups } \\
\hline & \multicolumn{2}{|c|}{1} & \multicolumn{2}{|c|}{2} & \multicolumn{2}{|c|}{3} & 4 \\
\hline 1 & \multicolumn{2}{|c|}{0} & \multicolumn{2}{|c|}{0} & \multicolumn{2}{|c|}{0} & 0 \\
\hline 2 & \multicolumn{2}{|c|}{4.3} & \multicolumn{2}{|c|}{2.6} & \multicolumn{2}{|c|}{1.6} & 0 \\
\hline 3 & \multicolumn{2}{|c|}{8} & \multicolumn{2}{|c|}{4} & \multicolumn{2}{|c|}{2} & 0 \\
\hline 4 & 8.3 & $8.6^{*}$ & 4.3 & $5.0^{*}$ & 3.0 & $4.0^{*}$ & 0 \\
\hline 6 & 9.0 & 9.6 & 7.3 & 8.3 & 6.3 & 7.0 & 0 \\
\hline 8 & 9.3 & 10.6 & 7.6 & 8.6 & 6.6 & 7.3 & 0 \\
\hline 10 & 9.3 & 10.3 & 8.0 & 8.6 & 5.5 & 6.6 & 0 \\
\hline 12 & 8.6 & 9.0 & 8.0 & 8.3 & 5.0 & 6.0 & 0 \\
\hline
\end{tabular}

* Chickens received booster dose from each group.

Table 5. Infectious bronchitis ELISA titres in groups of vaccinated and non-vaccinated chickens.

\begin{tabular}{|c|c|c|c|c|c|c|c|}
\hline \multirow{2}{*}{$\begin{array}{l}\text { Weeks post } \\
\text { vaccination }\end{array}$} & \multicolumn{7}{|c|}{ Groups } \\
\hline & \multicolumn{2}{|c|}{1} & \multicolumn{2}{|c|}{2} & \multicolumn{2}{|c|}{3} & 4 \\
\hline 1 & \multicolumn{2}{|c|}{634} & \multicolumn{2}{|c|}{195} & \multicolumn{2}{|c|}{123} & 35 \\
\hline 2 & \multicolumn{2}{|c|}{1950} & \multicolumn{2}{|c|}{1089} & \multicolumn{2}{|c|}{918} & 34 \\
\hline 3 & \multicolumn{2}{|c|}{3206} & \multicolumn{2}{|c|}{2089} & \multicolumn{2}{|c|}{1799} & 34 \\
\hline 4 & 3485 & $3600 *$ & 2192 & 3133* & 2074 & $2559^{*}$ & 50 \\
\hline 6 & 3525 & 3945 & 2301 & 3326 & 2153 & 2839 & 94 \\
\hline 8 & 3622 & 3963 & 2317 & 3334 & 2137 & 2832 & 55 \\
\hline 10 & 3358 & 3963 & 2307 & 3343 & 2123 & 2799 & 45 \\
\hline 12 & 3606 & 3973 & 2301 & 3358 & 2113 & 2780 & 34 \\
\hline
\end{tabular}

* Chickens received booster dose from each group.

- Positive control $=2278$

- Negative control $=215$ 
TRIALS FOR PREPARATION OF COMBINED INACTIVATED VACCINE

AGAINST RESPIRATORY VIRAL DISEASES OF POULTRY (ND-IB-ILT)

Table 6. Infectious bronchitis serum neutralizing antibody titres in groups of vaccinated and non-vaccinated chickens.

\begin{tabular}{|c|c|c|c|c|c|c|c|}
\hline \multirow{2}{*}{$\begin{array}{l}\text { Weeks post } \\
\text { vaccination }\end{array}$} & \multicolumn{7}{|c|}{ Groups } \\
\hline & \multicolumn{2}{|c|}{1} & \multicolumn{2}{|c|}{2} & \multicolumn{2}{|c|}{3} & 4 \\
\hline 1 & \multicolumn{2}{|c|}{8} & \multicolumn{2}{|c|}{8} & \multicolumn{2}{|c|}{8} & 2 \\
\hline 2 & \multicolumn{2}{|c|}{32} & \multicolumn{2}{|c|}{10} & \multicolumn{2}{|c|}{16} & 2 \\
\hline 3 & \multicolumn{2}{|c|}{64} & \multicolumn{2}{|c|}{32} & \multicolumn{2}{|c|}{16} & 0 \\
\hline 4 & 256 & $512^{*}$ & 32 & $128^{*}$ & 32 & $64 *$ & 0 \\
\hline 6 & 512 & 2048 & 128 & 1024 & 64 & 128 & 0 \\
\hline 8 & 512 & 2048 & 128 & 1024 & 64 & 128 & 0 \\
\hline 10 & 256 & 2048 & 128 & 512 & 64 & 64 & 0 \\
\hline 12 & 256 & 1024 & 128 & 512 & 64 & 16 & 0 \\
\hline
\end{tabular}

* Chickens received booster dose from each group.

Table 7. Laryngotracheitis serum neutralizing antibody titres in groups of vaccinated and non-vaccinated chickens.

\begin{tabular}{|c|c|c|c|c|c|c|c|}
\hline \multirow{2}{*}{$\begin{array}{c}\text { Weeks post } \\
\text { vaccination }\end{array}$} & \multicolumn{2}{|c|}{1} & \multicolumn{2}{|c|}{2} & \multicolumn{2}{c|}{3} & 4 \\
\hline 1 & \multicolumn{2}{|c|}{16} & \multicolumn{2}{|c|}{8} & \multicolumn{2}{|c|}{0} & 0 \\
\hline 2 & \multicolumn{2}{|c|}{32} & \multicolumn{2}{|c|}{16} & \multicolumn{2}{|c|}{16} & 0 \\
\hline 3 & \multicolumn{2}{|c|}{32} & \multicolumn{2}{|c|}{16} & & 8 & 0 \\
\hline 4 & 64 & $128 *$ & 32 & $64^{*}$ & 4 & $32 *$ & 0 \\
\hline 6 & 128 & 256 & 64 & 128 & 4 & 64 & 0 \\
\hline 8 & 32 & 256 & 128 & 128 & 4 & 64 & 0 \\
\hline 10 & 16 & 128 & 16 & 32 & 2 & 32 & 0 \\
\hline 12 & 16 & 64 & 8 & 16 & 2 & 8 & 0 \\
\hline
\end{tabular}

* Chickens received booster dose from each group.

\section{REFERENCES}

1. Barhoom, S.A., A. Forgacs and F. Solyom. 1986. Development of an inactivated vaccine against Laryngotracheitis (ILT) serological and protection studies. Avian Pathol., 15: 213-221.

2. Code of American Federal Regulation 1985. Published by the Office of the Federal Register National Archives Records Service. General Services Administration.

3. Cunningham, C.H. 1973. A laboratory guide in virology. $7^{\text {th }}$ Ed. Burgess Publishing Co. Minneapolis, Minnesota.

4. Daubeny, R. and W. Mansy. 1947. The occurrence of the Newcastle disease in Egypt. J. Comp. Pathol., 58: 189. 
5. El-Enbawy, M.I. 1990. Some studies on Candida albicans. Ph.D. Thesis, Microbiology; Fac. Vet. Med., Cairo Univ.

6. Gelb, Jr., J.K. Rosenberger, P.A. Fries, S., Sondra, S. Claud, E.M. Odor, J.E. Dohms and J.S. Jaeger. 1989. Protection afforded IBV vaccinated sentinel raised in commercial environmental. Avian Dis., 33: 764-769.

7. Gross, W.B. and H.S. Siegel. 1983. Evaluation of the heterophil / lymphocyte ratio as a measure of stress in chickens. Avian Dis., 27 (4): 972-979.

8. Hafez, H.M. 2006. Respiratory diseases of Poultrt: Diagnosis and Control. $7^{\text {th }}$ Sci. Conf. of the EVPA, March 6-9 $9^{\text {th }}, 2006$.

9. Hanson, L.E. and T.J. Bagust. 1991. Laryngotracheitis. In: Diseases of Poultry. $9^{\text {th }}$ Ed. B.W. Calnek, H.J. Barnes, C.W. Beard, W.M. Reid and H.W. Yoder, Jr., eds, Iowa State Univ. Press, Ames, Iowa, pp. 485-495.

10. Hofstad, M.S. 1984. Disease of poultry. $8^{\text {th }}$ Ed. Avian Infectious Bronchitis. Pp. 429-443.Iowa State Univ., USA.

11. Majujabe, K.A. and S.B. Hitchner. 1977. Antibody response to strain combination of Newcastle disease virus as measured by haemagglutination inhibition test. Avian Dis., 21: 576-584.

12. Mosmann, J. 1983. Rapid calorimetric assay for cellular growth and cytotoxicity assays. J. Immunol. Methods, 55-65.

13. Stone, D., M. Brugh, S.R. Hophins, H.W. Woder and C.W. Peard. 1978. Preparation of inactivated oil emulsion vaccines with avian viral mycoplasma antigen. Avian Dis., 22: 666-674.

14. Timms, L.M, and C.D. Bracewell. 1983. Cell mediated and humoral immune response of chickens to inactivated oil emulsion infectious bronchitis vaccine. Res. vet. Sci., 34: 224-230. 


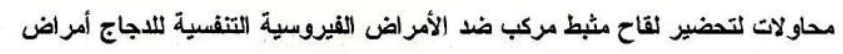

(النيوكاسل-الاتهاب الثعبى المعدى-إلتهاب الحنجرة و القصبة التهو أئية)

محمد عبد الخالق على عبد الخالق

هعزل بحوث الأمصال واللقاحات البيطرية-العباسية-مركز البحوث الزراعية - وزارة الزراعة -

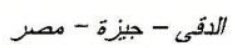

هذه الدراسة تمت على ، • دجاجة عمر ال بو يوم حيث قسمت الى أربع مجاميع رئيسـية

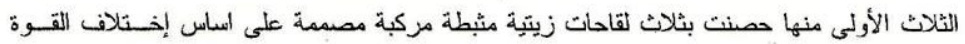

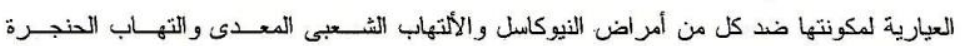

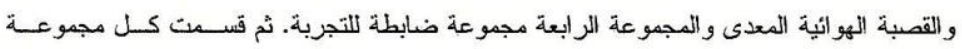

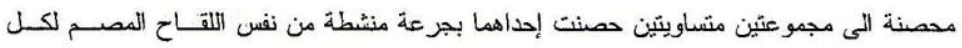

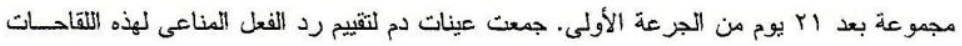

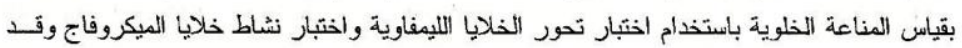

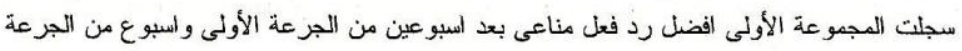

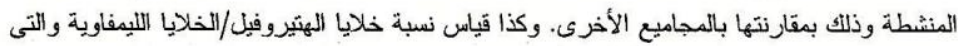
سجلت فيها المجموعة الأولى أقل نسبة مقارنة بالمجموعة الضابطة.

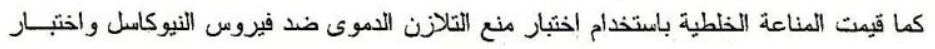

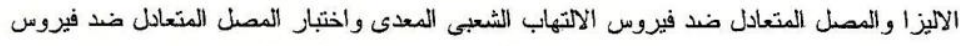

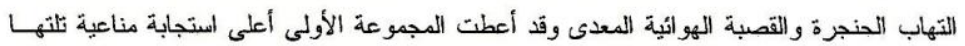

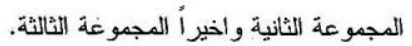

